\title{
Could Russia Embrace an Energy Transition?
}

\section{Tynkkynen, Veli-Pekka}

2020-10

Tynkkynen, V-P 2020 , ' Could Russia Embrace an Energy Transition? ' , Current History , vol. 119 , no. 819 , pp. 270-274 . https://doi.org/10.1525/curh.2020.119.819.270

http://hdl.handle.net/10138/321039

https://doi.org/10.1525/curh.2020.119.819.270

unspecified

publishedVersion

Downloaded from Helda, University of Helsinki institutional repository.

This is an electronic reprint of the original article.

This reprint may differ from the original in pagination and typographic detail.

Please cite the original version. 
"Ultimately, it may take a climate-related natural disaster to spur Russia toward sustainability."

\title{
Could Russia Embrace an Energy Transition?
}

\author{
Veli-Pekka TynkKynen
}

$\mathrm{V}$ ladimir Putin's Russia is deeply dependent on its fossil energy resources. This dependence is more profound than the dysfunctional dynamic that political economists have traditionally believed is the result of the intertwining of natural resources and political power. In Russia, fossil energy and state power are entangled to such an extent that the spheres of culture and identity are also caught in the web.

Fossil energy is central to Russia's economy. Oil, gas, and coal account for more than half the central government's budget revenue. The oil and gas industries make up a fifth of gross domestic product.

Yet Russia has all the material resources needed to become an ecological great power-a green giant. It has the level of technological development required to foster an energy transition toward renewable resources and a low-carbon economy. The country's vast forests offer great potential for bioenergy production, and its immense territory would allow it to develop a range of other forms of renewable energy.

Despite all this potential, the political elite's deep attachment to the rents and power it derives from hydrocarbons leaves it strongly opposed to calls for an energy transition. Russia is lagging far behind other world powers-notably China, the European Union, and the United States-in the deployment of renewable energy.

Industries devoted to resource extraction have been at the core of the Russian economy throughout its history-from furs, coal, and ore to oil and gas. The resulting practices resembled those found in other colonial contexts around the world: Siberian expanses were seen as exploitable resource-rich

VELI-PEKKA TYNKKYNEN is an associate professor of Russian environmental studies at the University of Helsinki. Parts of this essay have been adapted from his book The Energy of Russia: Hydrocarbon Culture and Climate Change (Edward Elgar, 2019). territories, and indigenous cultures were subjugated to serve the needs of the imperial center. During the Soviet era, industrialization relied on the heavy use of natural resources; industrial production targets were prioritized over social welfare and environmental protection.

Russia's deposits of oil, gas, coal, and uranium are not evenly distributed across its Eurasian territory-they are found mainly in the periphery. Developing these resources thus has required major infrastructural investments. Yet the more Russia has invested in energy infrastructure (gas and oil pipelines, ports, and so forth), the more its strategic choices have narrowed. Revenues from hydrocarbons help maintain the existing networks of political power, and long-term investments in fossil-fuel infrastructures generate institutional inertia, making a transition to a carbon-free energy system less feasible.

Nonetheless, the government in recent years has promoted clean energy, at least in its official pronouncements. Its national strategies have stressed the priority of increasing energy efficiency throughout the economy, from households to the public sector and industry, and have urged the deployment of renewables as a substitute for oil and coal in the domestic energy mix. Of course, using less oil and gas domestically would allow more of it to be sold on international markets at higher premiums.

These strategies may well indicate the direction in which the government would like to see its energy policies eventually shift. The intent also may be to reassure the rest of the world about its goals. But the projections appear overly optimistic. Russia's 2009 Energy Strategy states that the share of renewables in the national energy mix should cover 14 percent of total demand by 2030. More than a decade later, though, so-called new renewables (solar, wind, geothermal, and small-scale hydropower) account for just 1 percent of the nation's energy supply. 


\section{FOSSIL POWER}

Putin's return to the Russian presidency in 2012, after a four-year interim as prime minister, began a new expansion of the political system's autocratic elements. This has been evident in both domestic and foreign policy. The Kremlin's emphasis is now on geopolitical sovereignty. Its tone on climate change leans toward denial, while it works to strengthen the link between fossil energy and Russian identity.

Russia's status as a hydrocarbon superpower gives it the ability to influence the political choices of other countries with its energy exports. Yet Russian elites and the public are ambivalent about the idea that hydrocarbons serve as the fundamental basis of Russia's status or national identity. The elites are aware of the economic problems related to hydrocarbon dependence: exporting raw materials while importing goods puts Russia in the company of developing nations. Although a majority of Russians consider their country an energy superpower, many live in poverty and resent the wealth enjoyed by the elites.

Meanwhile, global energy markets have changed greatly during the past decade due to the growing importance of unconventional hydrocarbons (shale oil and gas) and renewable sources. This has undermined Russia's export prospects, forcing it to engage in more aggressive competition-as was demonstrated by Moscow's maneuvers during the spring of 2020. When the coronavirus pandemic led to a collapse in energy demand worldwide, Russia initially refused to strike a deal with OPEC and the Saudis to reduce its oil production volumes. Once the price collapsed, Russia finally went along, but the production cuts were too limited and came too late to calm the markets. Prices partially recovered only after global consumption of oil began to rise again.

Before the pandemic, Moscow saw little reason to defer to ambitious international climate objectives, such as the pledged emission cuts under the 2015 Paris Climate Agreement, and those set by the European Union's Green Deal policy (aiming to achieve a carbon-neutral economy by 2050) announced in December 2019. The Kremlin downplayed environmental responsibility while promoting a national identity based on hydrocarbons. A nation that sees its identity as intertwined with fossil energy is unlikely to take a progressive role in global climate politics. And Moscow has further distanced itself from Western-backed agendas during its intensified confrontation with the West in the past few years, particularly since Russia's 2014 annexation of Crimea and military intervention in Ukraine resulted in the imposition of US-European sanctions.

The Kremlin's notions of Russia's destiny as an energy superpower have been actively promoted by the hydrocarbon industry. The giant stateowned gas company Gazprom has run advertising campaigns to portray the industry as a guarantor of a uniquely Russian mix of neoconservative and traditional, patriarchal values, while casting Russian citizens and communities in submissive roles. These discourses, part of the regime's efforts to construct a hydrocarbon culture, are rooted in a nationalistic modernization ethos that has carried over from the Soviet era.

The governmental mentality visible in Gazprom's advertisements pursues various conservative objectives, but by far the most important is entrenching Putin's regime and its economic policy relying on the extraction of fossil energy. Hydrocarbon culture serves as a tool to prevent popular criticism of an economy that resembles those of developing states in its dependence on exporting raw materials. This energy culture opposes the modernization of Russia's economic and industrial policies. It also advocates authoritarian rule and the regime's great power ambitions.

Russia's energy culture distorts environmental policy as well. State-controlled national media propagate a climate-denial narrative, while stateowned energy firms block the development of more sustainable policies at the regional level.

\section{SKEWED VISION}

The severe effects of climate change should not come as a surprise to anyone, given the scientific evidence built up over the past few decades. But the Kremlin leadership tends to view climate change as beneficial, since other countries will suffer more than Russia. The narrative in the Russian media is that bad things may happen because of climate change, but Russia will not be affected. This story has been told to Russians since at least the 1990s.

The prevalent idea of Russia as a fortress surrounded by enemies skews security and risk perceptions. This parochial view of the world is 
unable to see climate change as a common problem facing all of humanity. Instead, Russian elites perceive global climate governance as a zero-sum game.

According to this worldview, the solution is not taking responsibility by reducing hydrocarbon production and consumption, but using thought control to instill climate denial at home while freeriding internationally, leaving other countries that are suffering more from global warming to assume the burdens of mitigation. Yet when those implementing mitigation measures, such as the EU, happen to be the main customers for Russia's energy exports, the fossil-based regime may perceive mitigation as a security threat.

Climate change will have global consequences for human security. It may cause conflicts and refugee crises in Asia, the Middle East, and Africa due to resource shortages. Yet such scenarios are almost completely absent from Russia's climate discussion. In the Russian media, refugee flows from the Middle East and Africa to Europe are depicted as a failure of the EU, and Moscow has tried to exploit the situation opportunistically. Yet the potential for climate change-induced Central Asian refugee flows to Russia is not considered.

In Russia, the warming climate will impose economic costs by thawing the permafrost that covers approximately 60 percent of the country's territory. Industrial, transportation, and housing infrastructure is vulnerable to permafrost thaw. Structures in these areas will be at risk of collapse in a warmer climate, as their foundations become unstable on the soft ground left behind by melting ice. The huge Norilsk diesel spill in June 2020 demonstrated these risks. At least 17,000 tons of diesel oil spilled into a lake and rivers flowing into the Arctic Ocean when the foundations of fuel storage tanks at a power plant collapsed after a heat wave that likely accelerated permafrost melting.

The majority of Russia's untapped hydrocarbon deposits are in the permafrost areas. Environmental change will darken the economic outlook for future projects to extract these deposits, which may eventually need to be written off as stranded assets. Russian energy companies have taken little action to hedge against this risk, even as some of their Western counterparts are announcing plans to begin a transition into renewables.

The Putin regime's nationalist-conservative shift makes it hard to imagine that Russia could take any meaningful role in the battle against climate change, especially given its failure to evaluate the associated transnational risks. But climate change is a security threat for all nations. Ultimately, it may take a climate-related natural disaster to spur Russia toward sustainability. For now, the nation remains a laggard, unable to profit economically or politically from the transition to a new carbonneutral world energy order.

The logic of a hydrocarbon culture is at odds with Russia's ambitions to rise to a higher level of technological progress. Developing more innovative industries, a prerequisite for transitioning toward a sustainable economy built on renewable energies, would necessitate abandoning that culture's practices and mentalities. Instead, the Kremlin is turning to both military and nonmilitary forms of aggression-a wide repertoire of tactics known as "hybrid warfare"-to compensate for the technological lead of Western countries and China.

Since 2015, Russia's National Security Strategy has stated that both direct and indirect means must be used in the global struggle for power to achieve a "strategic deterrent." Thus a rapid global transition to new energy technologies may be viewed by Moscow as a security threat that must be confronted with hybrid warfare. Russian backing and financing for far-right parties in the $\mathrm{EU}$ is one example of this kind of action: right-wing populists try not only to weaken the $\mathrm{EU}$, but also to dismantle its joint climate policy and prevent it from speaking with a common voice on energy and foreign policy. But building a more sustainable Russia, able to reap the benefits of the global energy transition, is not part of the Kremlin's strategy.

\section{ChANGE FROM WITHIN}

Under Putin, Moscow has continued the centuries-old practices of an empire that is violent toward its own people and the outside world, yet unable to harness Russia's bountiful resources and their potential to be part of a climate solution for the planet. Turning Russia into an internally strong and internationally respected player would require rethinking the objectives and rules of the game in both domestic and cross-border contexts. How can Russians foster change from within, and how can Russia's international partners encourage such a transformation?

Debunking hydrocarbon propaganda would be a first step. This might involve revealing the rationale as well as the actors behind specific promotional campaigns glorifying the hydrocarbon culture. Publishing such exposés will be difficult 
in an increasingly closed media environment, but they are necessary to show the Russian people why clinging to oil and gas will be perilous for them. Opposition leader Alexei Navalny's widely viewed videos exposing high-level corruption could provide a model for how civil society might play a role in such a campaign.

The next step would be to develop an argument laying out Russia's potential to become an ecological great power. The nation could achieve sustainability by unleashing its potential in renewable energy, as well as in carbon storage. It could do so by protecting its forests, bogs, and permafrost. This would be a path to great power status achieved not through coercion, but through soft power. Russia would be respected for the ecological services it provided for the global community and the renewable energies that would fuel its own sustainable economy.

Since Russia exports most of its energy commodities, ending its addiction to windfall rents from oil and gas will require international cooperation on decarbonization. The global energy industry must face concerted pressure to account for the environmental costs of production. It should adopt measures such as carbon pricing, corporate responsibility certificates, and strict monitoring of environmental impacts.

Only this kind of global framework can curb national subsidies for fossil fuel production, allowing renewable energy to compete on a fair basis.

As Russia's biggest export market, the EU possesses substantial leverage that it has failed to use in its relations with Moscow. It must speak with a common voice to exert the full potential of its buying power. Brussels should enforce strict environmental and social responsibility norms for all imported energy sources.

Here, the EU's Green Deal and its newly established Energy Union can play a central role. The Green Deal aims to decarbonize the commodity chains of imported natural resources entering the EU zone; the Energy Union is an effort to establish a unified voice in energy policy, especially vis-à-vis the EU's main trade partners. A coordinated energy policy on the EU level could effectively counter Russia's divide-and-rule strategy of using attractively priced bilateral energy deals to discourage moves toward a united European position.
Putin's entourage seeks to portray such efforts to promote clean energy as part of an anti-Russian conspiracy. Yet debunking the hydrocarbon culture does not mean hindering investment in Russia. Instead, it would clear the way for investment to be diverted to businesses that play a role in the shift to a low-carbon society. Such an approach would encourage Russia to take its place at the forefront of the energy transition rather than continue to play a spoiler role, unable to define its own fate.

Domestically, the ruling bargain based on oil and gas must be replaced by regionalized social contracts that are derived from local socioeconomic strengths. This would reap the full potential of natural and human resources in each locality and region, instead of leaving them to rely on Moscow for patronage. Hydrocarbon culture is the antithesis of regionally sustainable economies; it discourages innovation based on local resources. Instead, it pacifies both citizens and regional leaders by promising welfare and sustainability, though it is not able to deliver either. The current protests against domineering rule from Moscow in the far eastern province of Khabarovsk can be viewed as evidence of the failure of this hydrocarbon-based social contract.

\section{HOW TO BE A GREEN GIANT}

The geopolitical implications of a global transition to renewable energy are certain to pose risks for a monolithically ruled hydrocarbon culture like Russia's. Yet they represent a great opportunity for reshaping the country's society, politics, and economy on a more resilient and sustainable basis. The inevitable global energy transition has already started, but due to the Putin regime's refusal to recognize this reality, Russia is lagging far behind other powers in the competition to capitalize on the shift.

Moscow's resistance is not only self-defeating; it is also a threat to global peace and security. As long as Russia is unable to transform its economy, rewrite its social contract, and abandon the old model of hydrocarbon dominance, it will remain an unpredictable and dangerous player in a world that is gradually disengaging from fossil energy.

Although the prospect of hydrocarbons losing their profitability may appear distant, now is the time to prepare. Disasters such as the coronavirus pandemic could accelerate the transition away from oil and gas. Once a country falls behind in 
the race to deploy renewables on a large scale, it is very hard to catch up. Even if renewables are not a strategic factor in the near future, the ability to continue to do business as usual is eroding for fossil-dependent countries such as Russia.

If Russia reverses course and chooses to become an ecological great power in both words and deeds, shaping a new kind of culture and a new energy strategy that utilizes all the assets that its geography has to offer, the nation will flourish economically and its society will become more resilient. Its potentially enormous renewable energy resources could also offer solutions for a more sustainable world.

Russia could be the key to building a Eurasian electricity supergrid that would provide both transit and storage infrastructure across the region. Such a transnational project would allow Russia to sustainably harvest all of its potential-in agriculture, high-tech manufacturing, and education. The colossal structure and centralizing influence of the hydrocarbon culture would no longer block the nation's development.
Russia's relations with both Europe and China would be able to develop in more symmetric ways. A renewables-based electricity supergrid for Eurasia-stretching from Lisbon to Shanghaiwould position Russia and its regions as indispensable actors in the production, transit, and storage of clean energy. Trade relations emerging from this network would confer economic, social, and environmental benefits. They would also address common threats, reducing unhealthy dependencies while enabling urgently needed action on climate change.

Fossil energy, political power, and climate denial are intertwined in Russia to such an extent that building support for an ambitious policy of reducing emissions and transitioning from a fossilbased energy system to a carbon-neutral one will be extremely difficult, even in the event that relatively more progressive leadership comes to power. But Russia has much more to gain than to lose from coming to terms with reality and seizing its opportunity to become a leader in the global shift to renewable energy. 